\title{
Development of a Groundwater Management Model for the Project Shoal Area
}

\author{
prepared by \\ Gregg Lamorey, Scott Bassett, Rina Schumer, Douglas P. Boyle, \\ Greg Pohll, and Jenny Chapman
}

\author{
submitted to \\ Nevada Site Office \\ National Nuclear Security Administration \\ U.S. Department of Energy \\ Las Vegas, Nevada
}

September 2006

Publication No. 45223 
Reference herein to any specific commercial product, process, or service by trade name, trademark, manufacturer, or otherwise, does not necessarily constitute or imply its endorsement, recommendation, or favoring by the United States Government or any agency thereof or its contractors or subcontractors.

Available for sale to the public, in paper, from:

U.S. Department of Commerce

National Technical Information Service

5285 Port Royal Rd. S/D

Springfield, VA 22161-0002

Phone: 800.553.6847

Fax: 703.605.6900

Email: orders@ntis.gov

Online ordering: http://www.ntis.gov/ordering.htm

Available electronically at http://www.osti.gov/bridge

Available for a processing fee to the U.S. Department of Energy and its contractors, in paper, from:

U.S. Department of Energy

Office of Scientific and Technical Information

P.O. Box 62

Oak Ridge, TN 37831-0062

Phone: 865.576.8401

Fax: 865.576.5728

Email: reports@adonis.osti.gov 


\title{
Development of a Groundwater Management Model for the Project Shoal Area
}

\author{
prepared by \\ Gregg Lamorey, Scott Bassett, Rina Schumer, Douglas P. Boyle, \\ Greg Pohll, and Jenny Chapman \\ Division of Hydrologic Sciences \\ Desert Research Institute \\ Nevada System of Higher Education
}

Publication No. 45223

submitted to

Nevada Site Office

National Nuclear Security Administration

U.S. Department of Energy

Las Vegas, Nevada

September 2006

The work upon which this report is based was supported by the U.S. Department of Energy under contracts \#DE-AC52-00NV13609 and DE-AC52-06NA26383. Approved for public release; further dissemination unlimited. 
THIS PAGE LEFT INTENTIONALLY BLANK 


\begin{abstract}
This document describes the development of a user-friendly and efficient groundwater management model of the Project Shoal Area (PSA) and surrounding area that will allow the U.S. Department of Energy and State of Nevada personnel to evaluate the impact of proposed water-use scenarios. The management model consists of a simple hydrologic model within an interactive groundwater management framework. This framework is based on an object user interface that was developed by the U.S. Geological Survey and has been used by the Desert Research Institute researchers and others to couple disparate environmental resource models, manage temporal and spatial data, and evaluate model results for management decision making. This framework was modified and applied to the PSA and surrounding Fairview Basin. The utility of the management model was demonstrated through the application of hypothetical future scenarios including mineral mining, regional expansion of agriculture, and export of water to large urban areas outside the region. While the results from some of the scenarios indicated potential impacts to groundwater levels near the PSA and others did not, together they demonstrate the utility of the management tool for the evaluation of proposed changes in groundwater use in or near the PSA.
\end{abstract}


THIS PAGE LEFT INTENTIONALLY BLANK 


\section{CONTENTS}

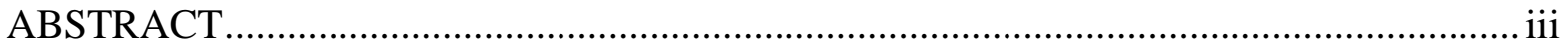

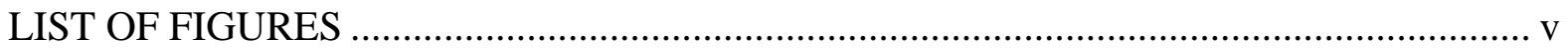

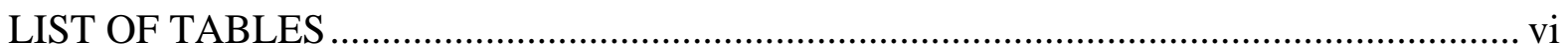

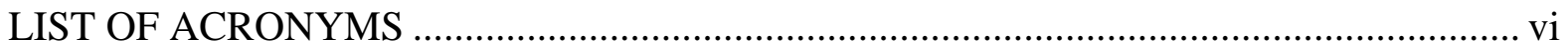

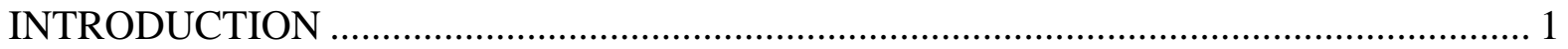

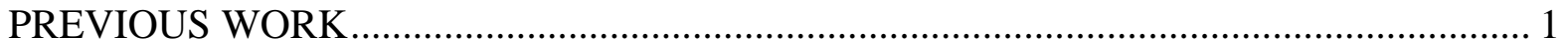

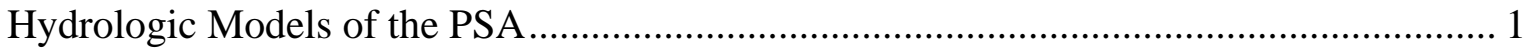

Tools for Management of Hydrologic Models .............................................................. 2

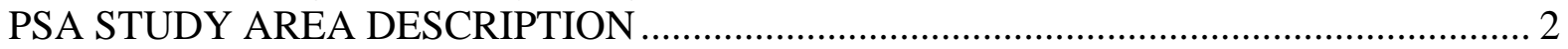

DEVELOPMENT OF THE PSA MANAGEMENT MODEL .................................................. 4

Conceptual Groundwater Model................................................................................... 4

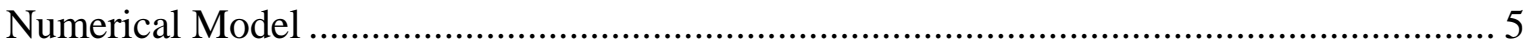

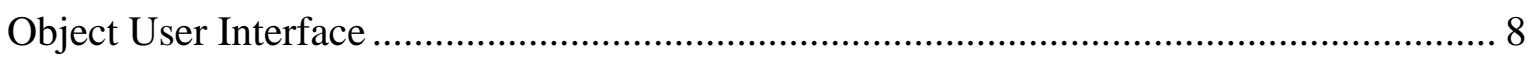

DEMONSTRATION OF PSA MANAGEMENT MODEL UTILITY ................................ 11

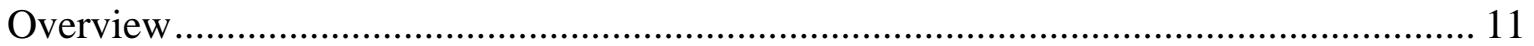

Development of Scenarios ....................................................................................... 12

Description of Scenarios ........................................................................................ 13

Scenario 1-Agriculture................................................................................................ 13

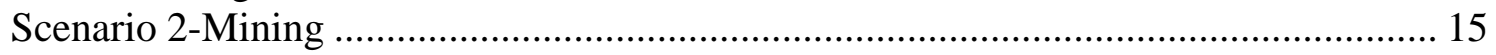

Scenario 3-Urban Water Diversion.......................................................................... 15

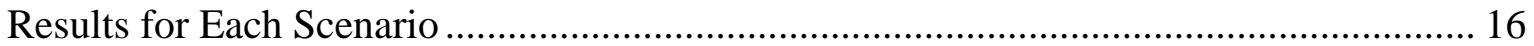

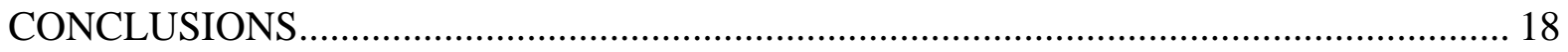

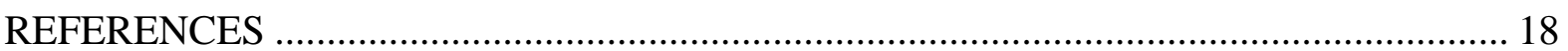

A compact disc containing the software developed is located in pocket on inside back cover

\section{LIST OF FIGURES}

1. Study area and model domain for the Fairview Basin groundwater flow model. ............... 3

2. Groundwater model grid showing constant head boundary and horizontal flow barrier... 5

3. Recharge rates used in the groundwater flow model........................................................... 6

4. Hydraulic conductivity zones used in the groundwater flow model..................................... 7

5. Simulated verses modeled heads for the groundwater flow model calibrated with no

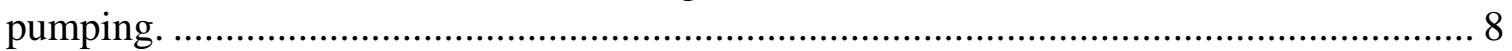

6. Object user interface with the control panel on the left and the GIS panel on the right..... 9

7. Object user interface showing the results of a model run where the drawdown has exceeded the threshold within the PSA.

8. Object user interface well table for entering and examining pumping scenarios in a

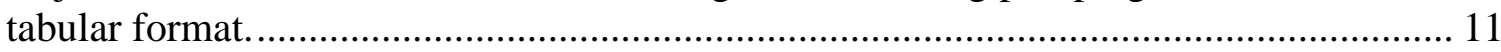

9. Distribution of wells for future pumping scenarios......................................................... 14

10. Results from (a) Scenario 1, (b) Scenario 2, and (c) Scenario 3........................................ 17 


\section{LIST OF TABLES}

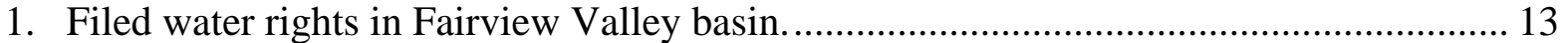

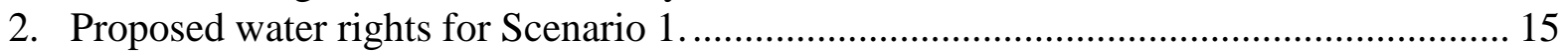

3. Proposed water rights for Scenario 2 ...................................................................... 15

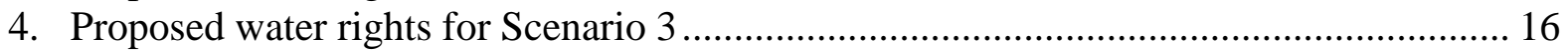

5. Area affected by hypothetical pumping scenarios.................................................. 18

\begin{tabular}{ll} 
AMSL & \multicolumn{1}{c}{ above mean sea level } \\
DOE & U.S. Department of Energy \\
FFACO & Federal Facility Agreement and Consent Order \\
GIS & geographic information system \\
OUI & Object User Interface \\
PSA & Project Shoal Area \\
USGS & U.S. Geological Survey \\
XML & Extensible Markup Language
\end{tabular}




\section{INTRODUCTION}

The Project Shoal Area (PSA), located about $50 \mathrm{~km}$ southeast of Fallon, Nevada, was the site of a 12-kiloton nuclear test on October 26, 1963 (DOE, 2000). The test, conducted at a depth of $367 \mathrm{~m}$ below land surface, was part of a program to enhance seismic detection of underground nuclear tests in active earthquake areas. The test took place in fractured granite along the crest of the Sand Springs Range.

In accordance with a Federal Facility Agreement and Consent Order (FFACO) with the State of Nevada, an area around the test site that may contain water unsafe for domestic and municipal use was delineated. The groundwater flow and transport models developed to delineate this boundary assume the continuation of current land and subsurface uses into the future. The U.S. Department of Energy (DOE) and State of Nevada regulators need a flexible groundwater management tool that will allow them to evaluate the impact of any proposed changes (scenarios) in groundwater use in the nuclear test vicinity.

The primary aim of this project is to develop a user-friendly and efficient management model of the PSA and surrounding areas that will allow DOE and state personnel to evaluate the impact of proposed water-use scenarios. The management model framework includes spatial and visualization tools to easily generate scenarios and analyze results. The hypothetical future scenarios developed to demonstrate the utility of the interactive groundwater management framework are intended to reflect a wide range of possible future situations that DOE and state personnel may need or want to evaluate in the PSA and surrounding area. While some or all of these scenarios may never occur, together they provide a broad range of possible impacts that demonstrate the utility of the management tool for the evaluation of proposed changes in groundwater use in or near the PSA. The software developed is described below and a copy is included on a compact disc located at the back of this report.

\section{PREVIOUS WORK}

\section{Hydrologic Models of the PSA}

Initial hydrologic investigations in support of the Shoal underground nuclear test (University of Nevada, 1965) involved the drilling of several deep wells and provided a thorough description of the local hydrologic system. Maxey (1967) characterized the groundwater system as dominated by recharge in the Sand Springs Range and discharge in the adjacent lowlands. Hazelton-Nuclear Science (1965) used this conceptual model to estimate the extent of contaminant transport. They concluded that slow groundwater velocities and radioactive decay limit the occurrence of hazardous aqueous concentrations of radionuclides to within $1,000 \mathrm{~m}$ of the immediate detonation area.

The next major period of investigation began in 1996 when corrective action work under the FFACO was initiated. Investigations from 1996 to 1998 obtained field data to support predictions of contaminant transport. This included determination of the hydraulic gradient in the test area, the permeability and porosity of the Sand Springs granite, recharge conditions, and information on the migration of contaminants from the test area. These data were incorporated into a numerical model to predict radionuclide transport (Pohll et al., 
1998, 1999). This model could not reproduce some of the field data, including head measurements and chemical and isotopic data.

Investigations and modeling from 1999 through 2003 addressed the problems encountered in the 1998 model. A Data Decision Analysis was performed to guide the investigation and data collection methods for minimizing the uncertainty in the groundwater flow and transport model predictions. The results of the Data Decision Analysis were used to propose three additional activities: vadose zone modeling, a two-well tracer test and an environmental tracer/deep-well hydraulic characterization well-nest. Data from these activities were used to refine the 1998 model (Pohlmann et al., 2003). This refinement included the representation of a low-conductivity shear zone to the east of the test site.

\section{Tools for Management of Hydrologic Models}

Researchers at the Desert Research Institute, in collaboration with the U.S. Geological Survey (USGS), have recently developed and implemented a computer application, Object User Interface (OUI), to provide the general framework needed to couple disparate environmental resource models and manage temporal and spatial data. The OUI is a map-based common interface for running computer hydrologic models as well as acquiring, browsing, organizing, and selecting spatial and temporal data. The OUI is based in Java and Extensible Markup Language (XML) and will run on most computer operating systems (e.g., windows, Solaris, MAC OS, etc.) without modification. The OUI is an "open source" computer code that is available at no cost to the user. The Desert Research Institute and the USGS have recently developed and applied real-time OUI-based decision support tools for water managers (e.g., U.S. Bureau of Reclamation, U.S. Army Corps of Engineers, U.S. Natural Resource Conservation Service) in several large watershed systems in the Western United States (e.g., Rio Grande, Gunnison River, Yakima River, Carson-Truckee river systems). Several of these systems included representation of groundwater-surface water interactions within the watershed systems that are critical to decision making and scenario analysis for water resource management. The OUI-based software was modified in this project to implement an OUI-based groundwater management tool for the DOE and state water managers.

\section{PSA STUDY AREA DESCRIPTION}

The PSA is a 10.4- $\mathrm{km}^{2}$ area in the Sand Springs Range, Churchill County, Nevada, that was withdrawn from the U.S. Bureau of Land Management for the Shoal nuclear test (Figure 1). Ground zero of the Shoal nuclear test is located near the middle of the PSA at a depth of $367 \mathrm{~m}$ below the land surface elevation of 1,594 $\mathrm{m}$. The test site is on the crest of the Sand Springs Range on a minor intramountain plateau named Gote Flat. The range trends north-south between Fairview Valley to the east and Fourmile Flat to the west, with about $500 \mathrm{~m}$ of relief between range and valley. There are no permanent streams or lakes, though a major intermittent drainage course follows Ground Zero Canyon, near the test site, to Fairview Valley. Sparse, low vegetation covers the area. Valleys in the region are semi-arid, and the mountains subhumid. Annual precipitation for the PSA is estimated between 20 and $30 \mathrm{~cm}$. Temperatures range from $38^{\circ} \mathrm{C}$ in July and August to $-18^{\circ} \mathrm{C}$ in December and January. 
The Sand Springs Range is a fault-block mountain defined by nearly vertical northeast- and northwest-trending faults, typical for a range in the Basin and Range province. The range is predominantly Cretaceous-age granite with adjacent metamorphosed Paleozoic

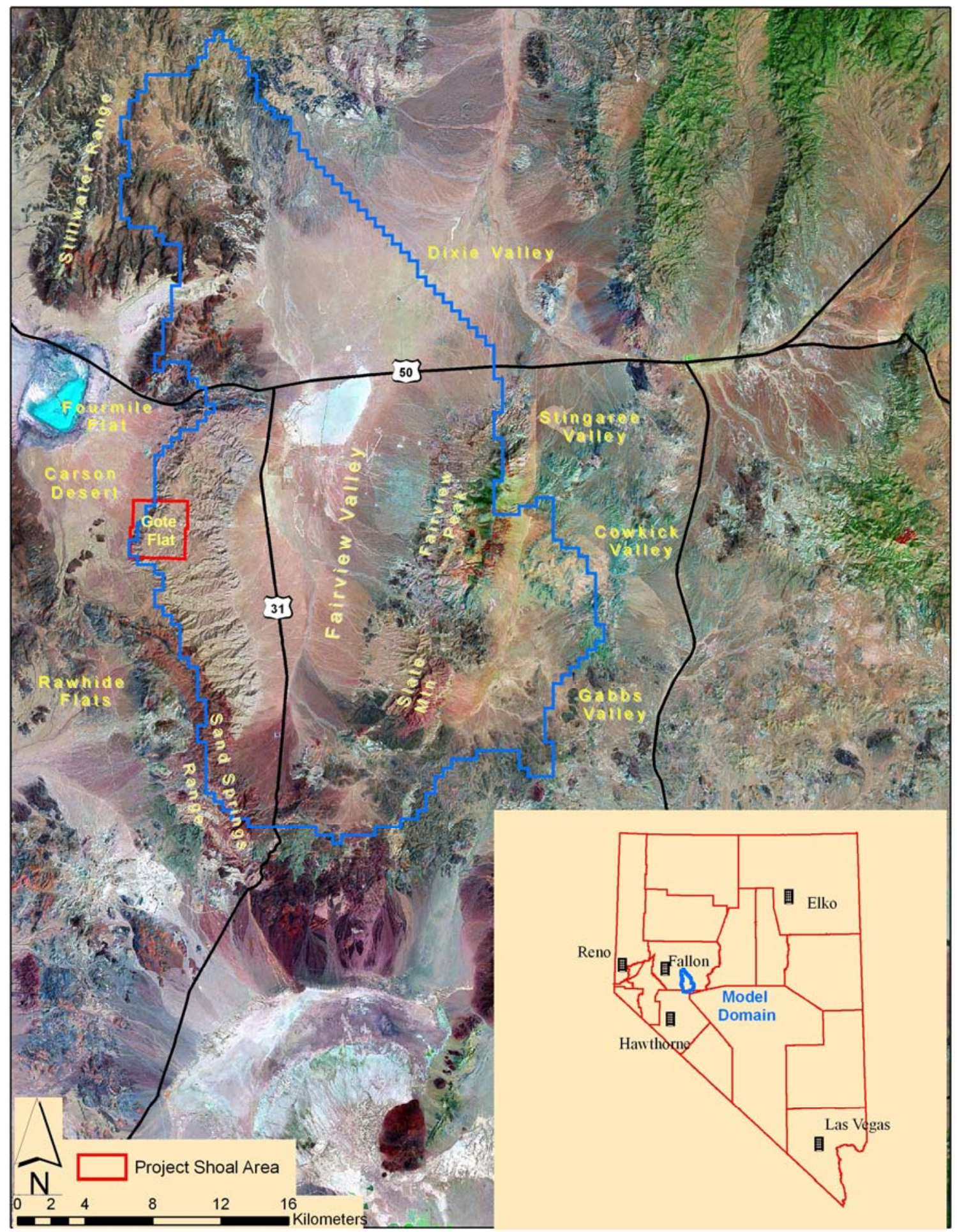

Figure 1. Study area and model domain for the Fairview Basin groundwater flow model. 
and Mesozoic marine sediments. To the east, Fairview Valley contains a thick sequence (up to 1,765 m) of Tertiary- and Quaternary-age alluvial and aeolian sediments. On the west, Fourmile Flat contains alluvial and aeolian sediments, with a thickness of about $395 \mathrm{~m}$, underlain by a west-sloping crystalline basement extending from the Sand Springs Range. The area is relatively active tectonically, with high- and moderate-angle, northeast- and northwest-trending faults within the center of the Sand Springs Range.

The highland area of the Sand Springs Range is a regional groundwater recharge area, with discharge occurring in the Fourmile Flat area to the west and Fairview Valley to the east. Site characterization data indicate that the groundwater divide separating flow to Fourmile Flat from flow toward Fairview Valley occurs west of the nuclear test site.

\section{DEVELOPMENT OF THE PSA MANAGEMENT MODEL}

\section{Conceptual Groundwater Model}

A groundwater flow model of the Fairview Valley basin was constructed to assess the impact of various water-use scenarios on the hydraulic heads in the PSA. This model is based on the Fairview Basin model developed by Pohlmann et al. (2003) that was used to ensure consistency between the boundary conditions of flow and transport models centered on the PSA and the known hydrogeologic conditions constraining the regional flow system. A major difference between the Pohlmann et al. (2003) Fairview basin model and the model presented here is the software used to simulate groundwater flow. Pohlmann et al. (2003) used FEFLOW, a proprietary finite-element simulation package available from the WASY Institute for Water Resources Planning and Systems Research, LTD. For this project, MODFLOW, a public domain finite-difference code supported by the USGS, was used to keep the management model "open source" and nonproprietary.

Groundwater in Fairview Basin originates from precipitation in the mountain ranges that surround the valley, including the southern Stillwater Range on the northwest, the Sand Springs Range on the west, and Fairview Peak and Slate Mountain on the east. Groundwater moves laterally toward Fairview Valley primarily through fractures in the crystalline rock. Alluvium thickness in the Fairview Valley has been estimated using gravity measurements to range from approximately $1,770 \mathrm{~m}$ on the western margin of the basin to approximately 1,220 $\mathrm{m}$ on the eastern margin (University of Nevada, 1965). Hydraulic properties of the basin-fill material have been determined from pumping tests near the western margin of the valley and at Frenchman's Station, near the center of the valley. Hydraulic properties of the crystalline rock are controlled by numerous high-angle faults and associated fractures and have been studied with a two-well tracer test and an environmental tracer/deep-well hydraulic characterization nest (Carroll et al., 2001; Mihevc et al., 2000; Reimus et al., 2003).

Recharge in Fairview Basin was estimated by Harrill and Hines (1995) by dividing the basin into elevation zones. Elevations below 1,524 $\mathrm{m}$ are assumed to contribute no recharge, elevations between $1,524 \mathrm{~m}$ and $1,829 \mathrm{~m}$ are estimated to contribute $0.76 \mathrm{~cm} / \mathrm{yr}$, and elevations above 1,829 are estimated to contribute $2.4 \mathrm{~cm} / \mathrm{yr}$. Pohll et al. (1998) estimated a recharge rate of $1.5 \mathrm{~cm} / \mathrm{yr}$ at an approximate land surface elevation of 1,620 m using thermal profiles in Shoal wells, while a model of the vadose zone at the PSA suggests recharge rates from near zero to $0.116 \mathrm{~cm} / \mathrm{yr}$ (Pohll, 1999). 
Natural discharge from the Fairview Basin occurs as lateral underflow toward Dixie Valley to the northeast. Harrill and Hines (1995) estimated that this discharge occurs at a rate of $7,774 \mathrm{~m}^{3} / \mathrm{d}$ and assumed that evapotranspiration is negligible in comparison.

\section{Numerical Model}

The numerical model is a two-dimensional representation of unconfined flow in the Fairview Basin consisting of 3,175 square elements with sides of $500 \mathrm{~m}$ (Figure 2). The model domain extends $48 \mathrm{~km}$ north to south and up to $28 \mathrm{~km}$ east to west. Boundaries are noflow (impermeable) with the exception of a 3.2-km section bordering Dixie Valley with a specified head boundary (Dirichlet condition). Heads on this boundary are assigned a value of 1,184 m above mean sea level (AMSL) based on the water level measured in a nearby well at the U.S. Navy Range Site and the water table map of Cohen and Everett (1963). Recharge is applied to the model based on elevation zones as reported by Harrill and Hines (1995) and shown in Figure 3.

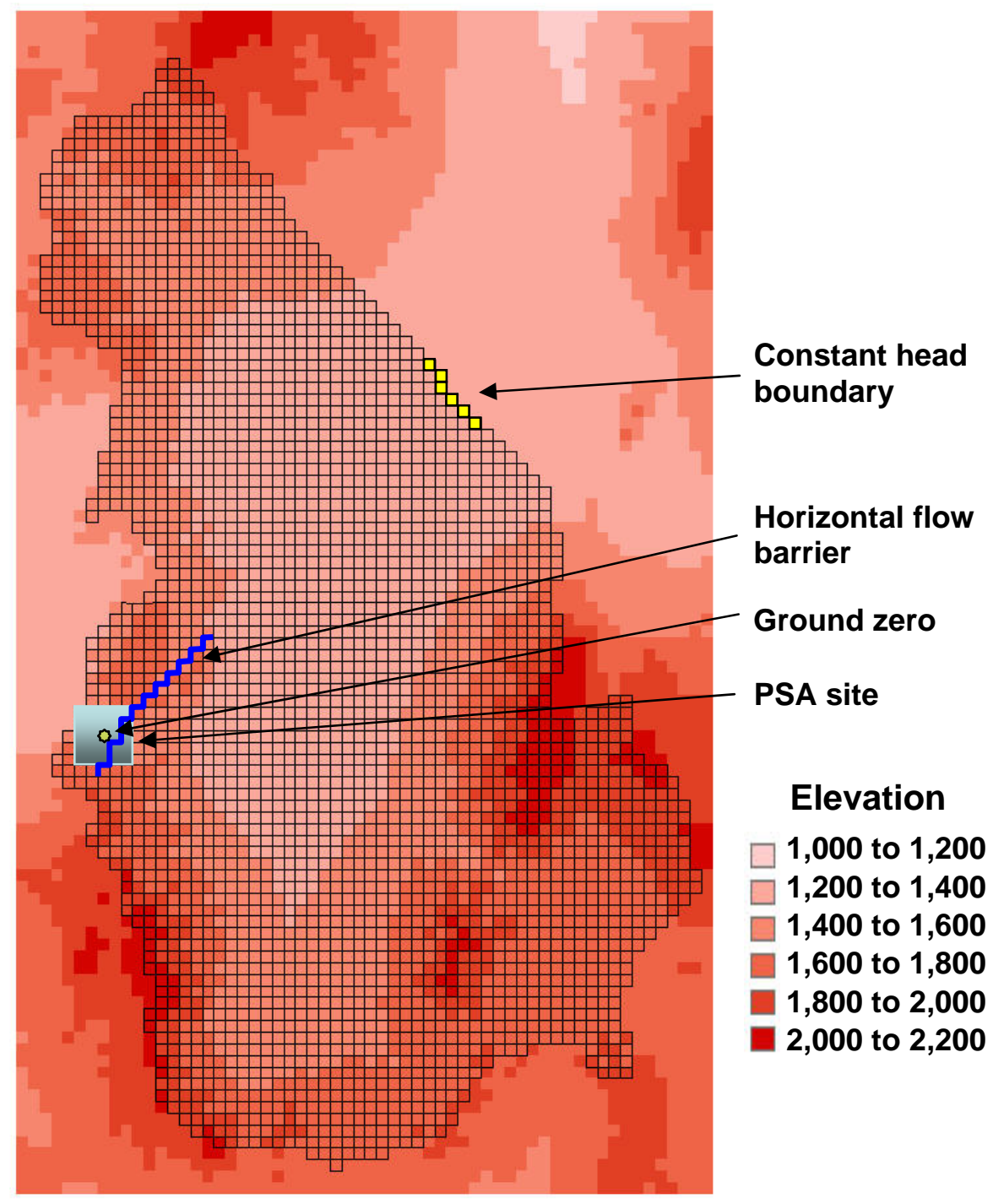

Figure 2. Groundwater model grid showing constant head boundary and horizontal flow barrier. 


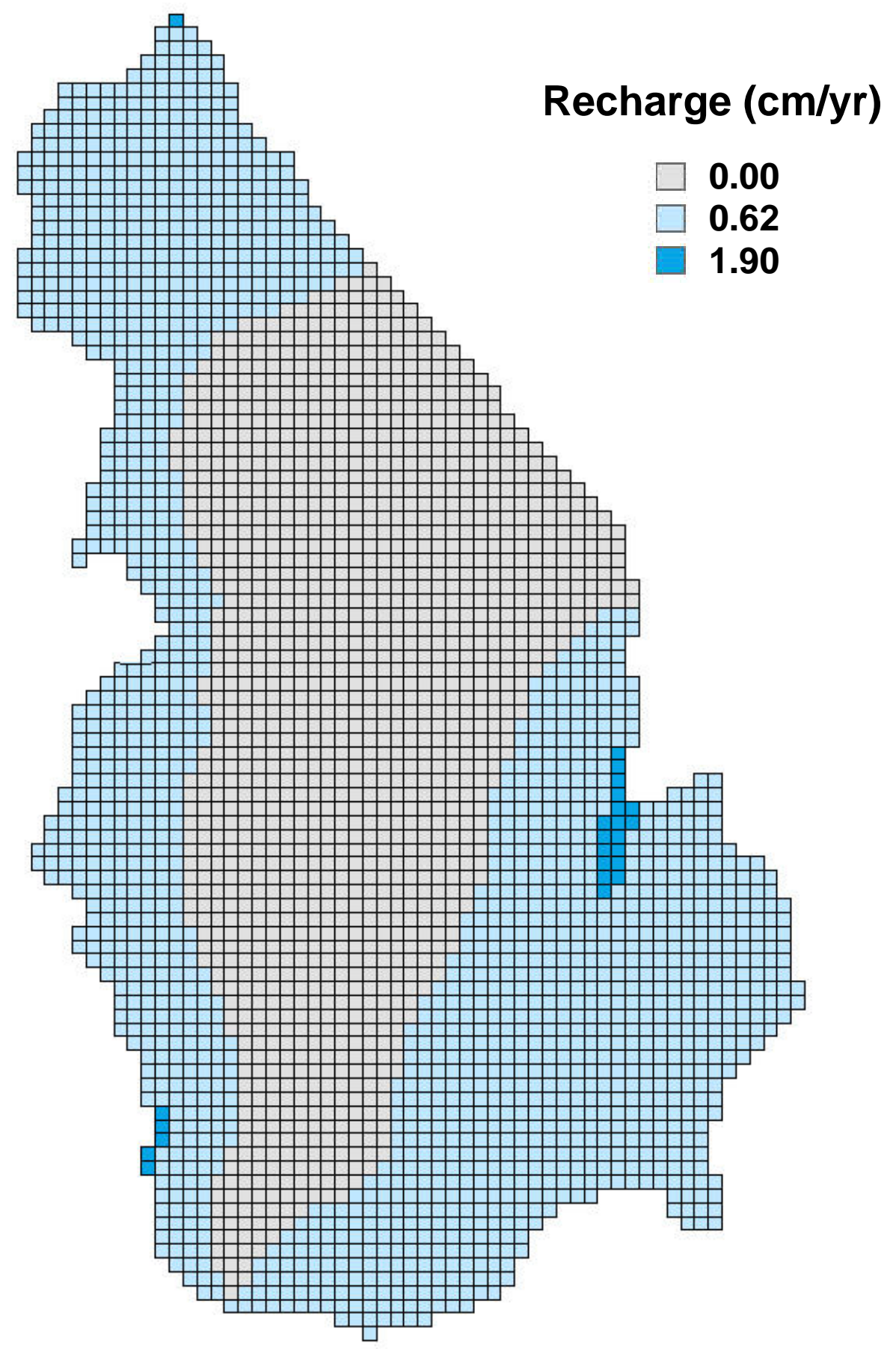

Figure 3. Recharge rates used in the groundwater flow model.

The model is divided into two zones for the purpose of assigning hydrologic properties. Zone I represents the basin-fill aquifer and Zone II represents the crystalline rock aquifers (Figure 4). Specific yield is set to 0.3 for Zone I and 0.019 for Zone II, based on the porosity of each unit. Specific storage is set to $1 \times 10^{-5}$ for both zones. The MODFLOW 
horizontal flow barrier package is used to simulate the low-conductivity shear zone to the east of the test site (Figure 2). The model is calibrated to steady-state conditions with the hydraulic conductivities determined by the PEST parameter estimation engine to be $476 \mathrm{~m}^{2} / \mathrm{d}$ for Zone I and $5.0 \mathrm{~m}^{2} /$ day for Zone II. These values are consistent with those used by Pohlmann et al. (2003) and pumping test estimates (University of Nevada, 1965; Mihevc et al., 2000).

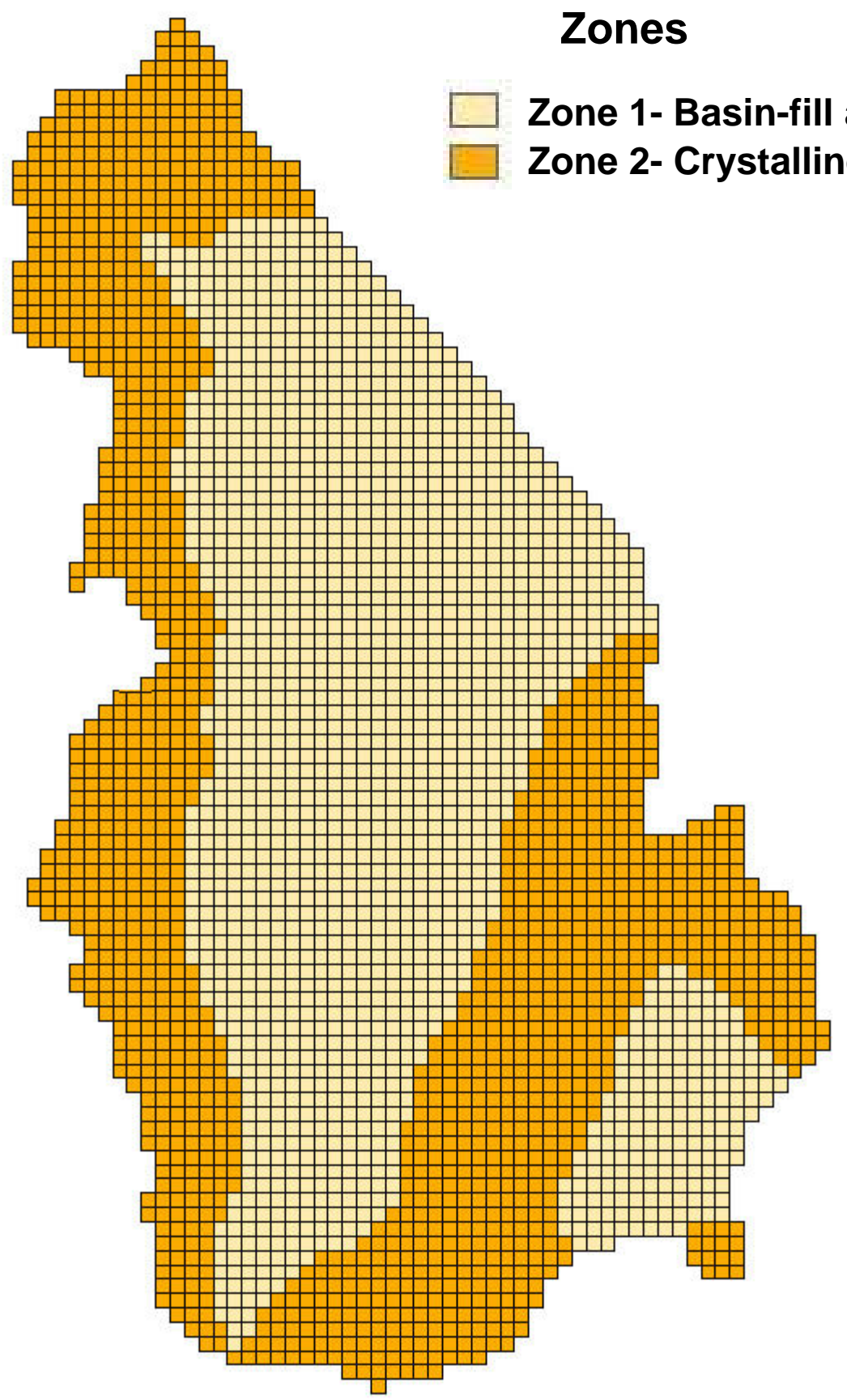

Figure 4. Hydraulic conductivity zones used in the groundwater flow model. 
Comparison of hydraulic head predicted by the model with those measured in the field support the model simulation of the Fairview Basin flow system (Figure 5). Heads in the basin-fill aquifer (Navy, Frenchman's Station , HS-1) and heads near the summit of the Sand Springs Range (HC-1, HC-2) are within $2 \mathrm{~m}$ of measured values. Several of the deep-well head measurements to the east of the test site show very high spatial variability due to structural features that cannot be represented in this model. These measurements are reconciled in more detailed three-dimensional models of the PSA by Pohlmann et al. (2003).

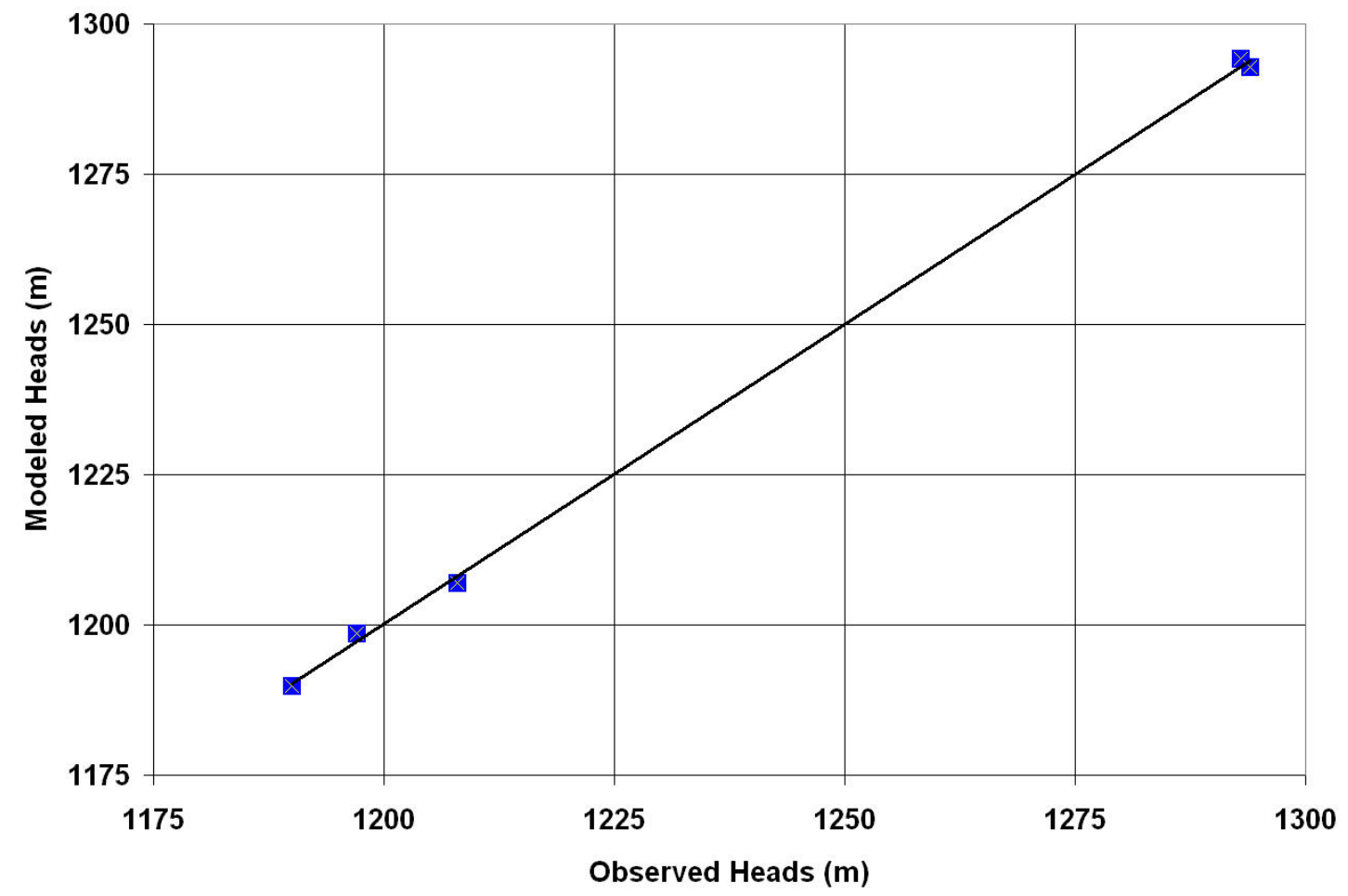

Figure 5. Simulated verses modeled heads for groundwater flow model calibrated with no pumping.

\section{Object User Interface}

The OUI is a map-based framework for models and modeling data developed and maintained by the USGS (www.brr.cr.usgs.gov/projects/ SW_precip_runoff/mms). The OUI provides a common interface for running models, as well as acquiring, browsing, organizing, displaying, and selecting spatial and temporal data. The OUI is highly configurable through the use of a user-modifiable, text-based control file that is written in XML.

The OUI is displayed on a computer screen as a control panel and a geographic information system (GIS) panel (Figure 6). Themes consisting of spatial information such as elevation, roads, and model grids can be activated on the GIS panel from the control panel. The control panel also allows information to be entered for model setup, control of model execution, and viewing of model results. Model results can be viewed as themes or animations of state variables such as hydraulic heads and drawdown. 


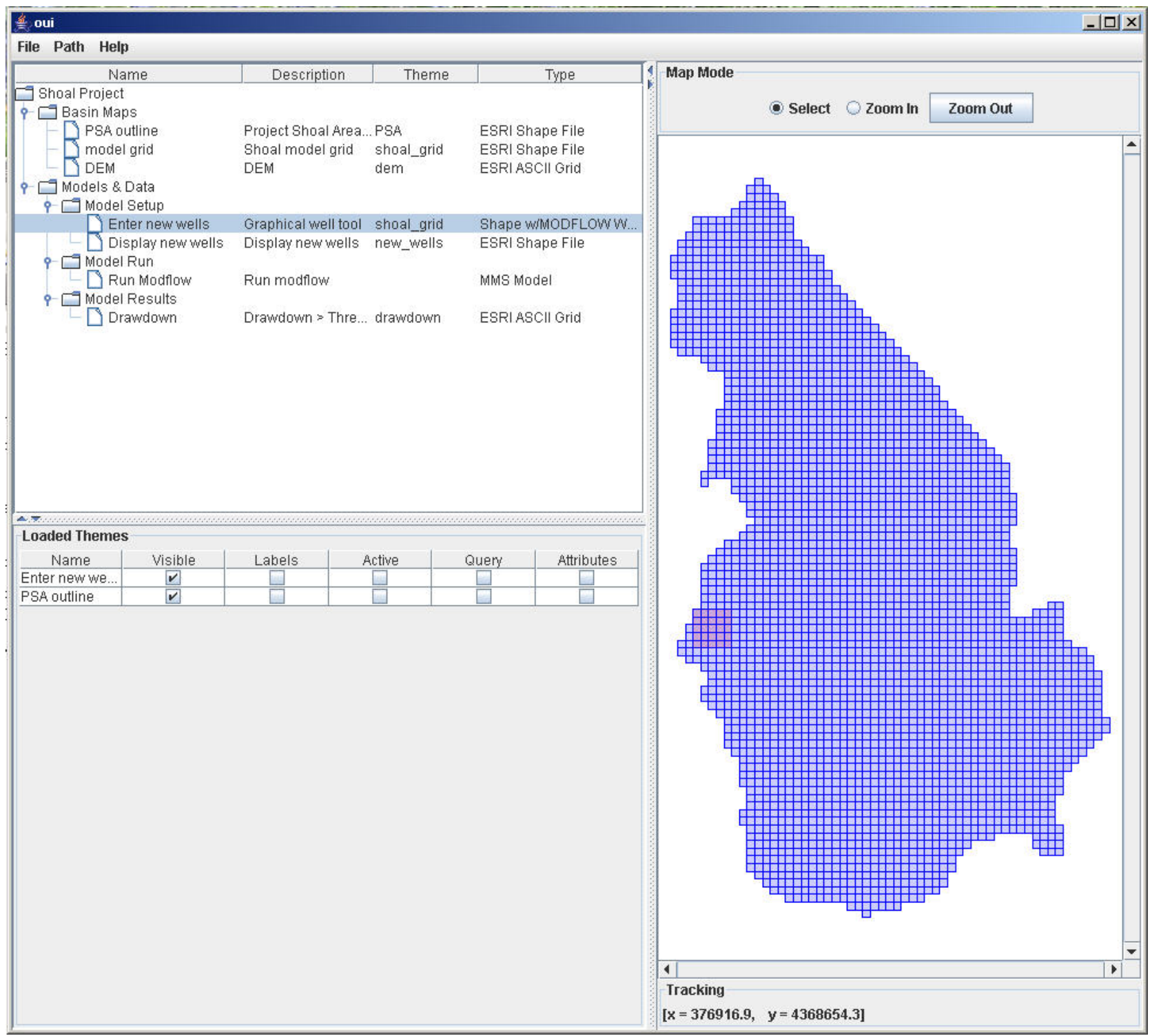

Figure 6. OUI interface with the control panel on the left and the GIS panel on the right.

Enhancements to the OUI for this project include enabling the OUI to run MODFLOW and developing of a tool for entering pumping scenarios. Linking the OUI to MODFLOW required the modification of the OUI Java and XML code to write and read MODFLOW files and execute the MODLOW computer application. For example, information describing a MODFLOW well (location, pumping rate, etc.) is entered and displayed using the OUI and then written in the MODFLOW well file format prior to executing MODFLOW. Following a MODFLOW run, model output such as drawdown are read and displayed by the OUI.

One objective of this project was to build a tool within the OUI that allows a user to determine if future pumping scenarios lead to drawdown within the PSA boundary that exceeds a threshold. To facilitate this, a dialog box was created that informs the user at the end of a MODFLOW run if a preselected threshold value of drawdown has been exceeded at 
the PSA site. If the model results indicate that the drawdown within the PSA exceeds this threshold, a message box is presented to the user with this information (Figure 7).

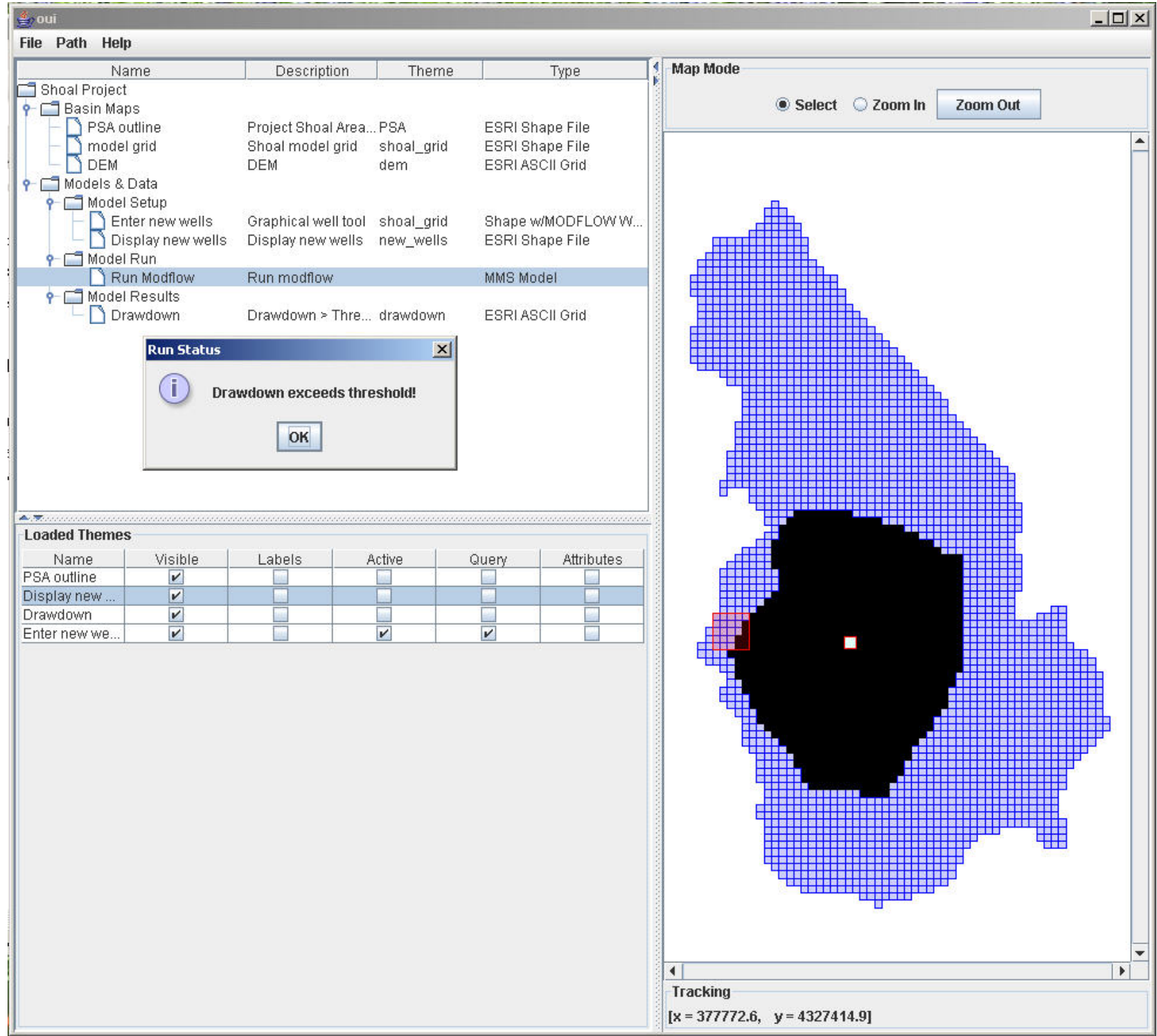

Figure 7. OUI interface showing the results of a model run where the drawdown has exceeded the threshold within the PSA.

The OUI tool developed for entering information about pumping scenarios can be used in two modes: point-and-click, and tabular entry (Figure 8). Point-and-click entry entails clicking the mouse on the appropriate model grid location, a dialog box is then activated for entry of the pumping rate. Tabular entry entails entering $\mathrm{x}$ - and $\mathrm{y}$-coordinates and the corresponding pumping rate. Once the information is entered, each scenario can be saved to a file for future use. Any projection can be used for the $\mathrm{x}$ - and $\mathrm{y}$-coordinates of the model and the pumping scenarios. However, if a UTM projection is used, there is an option to enter the well locations as Township, Range, and Section. This option can be useful since well logs often use these designations. 


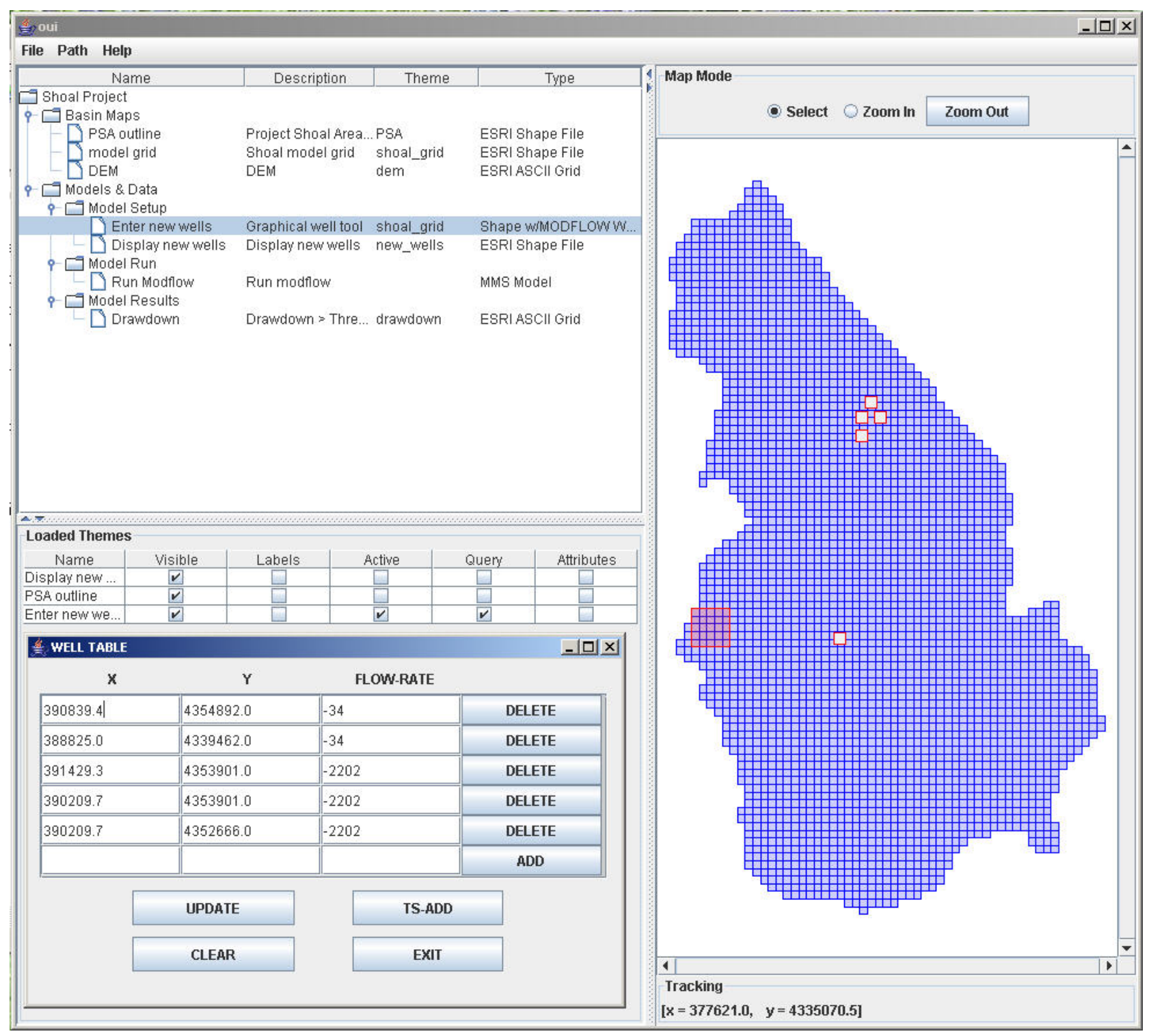

Figure 8. OUI well table for entering and examining pumping scenarios in a tabular format.

\section{DEMONSTRATION OF PSA MANAGEMENT MODEL UTILITY}

\section{Overview}

The purpose of the PSA management model is to determine the potential for future groundwater withdrawals to alter the groundwater flow system adjacent to the PSA. Although the groundwater flow model used within the management model does not simulate radionuclide transport or flow, it provides an indication of the potential changes due to increased pumping activities. The site-scale flow and transport model that was used to calculate the contaminant boundary assumed that the groundwater will remain in steady-state or equilibrium conditions. Therefore, if pumping rates increase within the Fairview Basin, it is possible that the water levels and associated flow directions and magnitude may change in the vicinity of the PSA. This management model will highlight changes that would 
potentially intersect the PSA such that the high-resolution flow and transport model can be updated to reflect the new conditions at the site.

Declining water levels (drawdown) is the metric used to determine potential changes in the groundwater system near the PSA. The OUI has the capability of presenting numerical values of drawdown, but the user may be most interested in significant water level declines that intersect the PSA. All scenarios presented in this report use a drawdown threshold of $1 \mathrm{~m}$ to show whether increased pumping influences the groundwater system. The user has the capability of changing the drawdown threshold within the OUI.

In the following sections, the details and results of several hypothetical future scenarios are described. The scenarios were developed to demonstrate the utility of the interactive groundwater management framework and are intended to reflect a wide range of possible future situations that DOE and state personnel may need or want to evaluate in the PSA and surrounding area. While some or all of these scenarios may never occur, together they provide a broad range of possible impacts that demonstrate the utility of the management tool for evaluation of the impact of proposed changes in groundwater use in or near the PSA (e.g., pumping wells) on radionuclide migration (i.e., contaminant boundary). For each scenario, the calibrated MODFLOW model was run in a transient mode for a 100-year period.

\section{Development of Scenarios}

For the purpose of demonstrating the utility of the PSA groundwater management tool, a few general scenarios were developed using scenario theory. Scenario creation for any region is driven by the single overlying question of how a region might change (Shearer et al., 2006) given a specific change in the existing system. Properly framing this question drives scenario-based studies. In this project, the focal issue is how potential changes in land use impact groundwater supply.

In general, change within a region is influenced by a combination of technological, economic, social, political, and environmental factors. Since future changes are undefined, scenarios must be formulated within a range of uncertainties. Further, driving factors that influence change may operate within the region or may be contained within macro-scale (outside the region) forces (Schwartz, 1996).

Based on a site visit and discussions with both residents and nonresidents familiar with the area, three key uncertainties in future land-use emerged. They are:

1. Will mineral mining - specifically gold and silver-increase in the region?

2. Is regional expansion of agriculture going to occur?

3. Will demands for water in large urban centers outside the region result in water demand within the region?

These three key uncertainties were translated into three scenarios, distinguished by type of water use:

- Scenario 1-Agriculture

- $\quad$ Scenario 2-Mining

- Scenario 3-Urban Water Diversion 
All of the scenarios assume current water rights are fulfilled by allowing pumping to occur at the designated duty of each water right. All scenarios restrict the total amount of pumping to the perennial yield of the Fairview Basin. Though multiple scenarios are likely to exist in conflict if they occur together, the tool is capable of combining aspects, and subsequently well pumping rates, from any of the scenarios into a single outcome.

The suite of scenarios is designed to show an adequate range of the possible policy and land-use decisions that may occur in the future. Figure 9 shows the existing pumping wells and possible distribution of new wells by scenario and should be used as a spatial reference for understanding the scenario descriptions that follow.

\section{Description of Scenarios}

\section{Scenario 1-Agriculture}

The remote location of the Fairview Basin and the relatively low amount of private land yields very little change in land use for the region. The three existing water rights continue pumping at their current rates. These water rights are detailed in Table 1.

Table 1. Filed water rights in Fairview Valley basin.

\begin{tabular}{lccrl}
\hline \multicolumn{1}{c}{ Owner } & Rights & Date & $\begin{array}{c}\text { Annual Duty } \\
\text { (m/day) }\end{array}$ & Notes \\
\hline Edward H. Stark, Sr. & 2 & $1 / 4 / 1938$ to 3/5/1946 & 48.94 & Stock diversion \\
Jerome Masterpool & 1 & $7 / 23 / 1982$ & 56.27 & Stock diversion \\
Fallon Naval Air Station & 2 & $5 / 7 / 1987$ to $11 / 19 / 1993$ & 122.35 & Unknown use \\
\hline
\end{tabular}

Agriculture gains greater emphasis throughout the region. Water applicants successfully negotiate between the U.S. Department of Defense, the Nevada State Public Lands office, and the State Engineer's office to certify their water rights, allowing them to pump their water. The negotiations result in three center-pivot alfalfa fields to be allowed on U.S. Department of Defense lands and two new stock locations on public land. For applicants who filed for irrigation rights, annual duties are calculated by assuming the pumping will only occur for a third of the year, or the effective irrigation season. Applicants filing for stock water rights are given the right to pump throughout the year.

Collectively, the three granted agriculture crop production groundwater rights allow pumping to yield 6,607 $\mathrm{m}^{3} /$ day (Table 2 ). The two additional stock ponds are pumped to yield $69 \mathrm{~m}^{3}$ /day. The combined total annual pumping for Scenario 1 and existing water rights yield $6,903 \mathrm{~m}^{3} /$ day. 


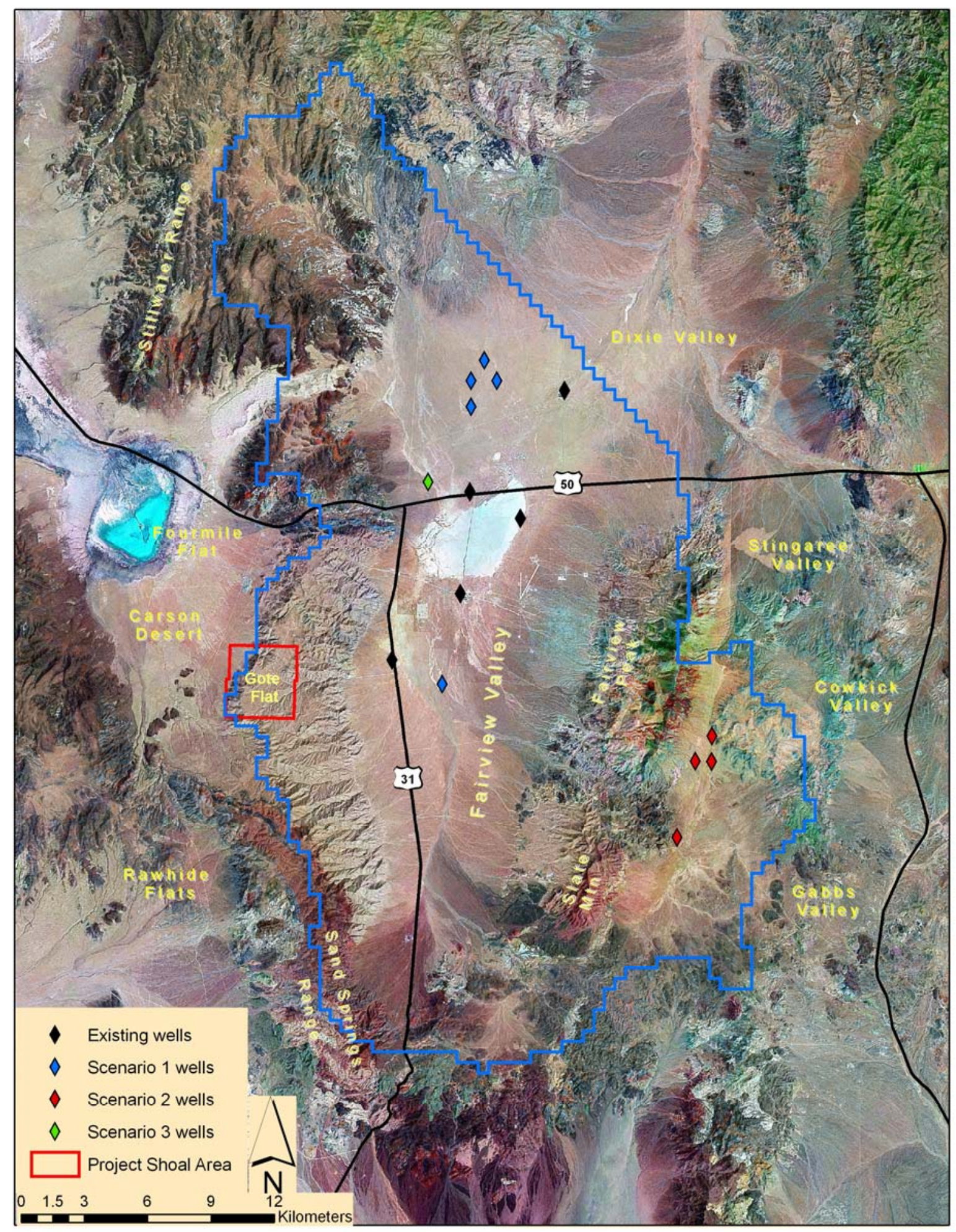

Figure 9. Distribution of wells for future pumping scenarios. 
Table 2. $\quad$ Proposed water rights for Scenario 1.

\begin{tabular}{cccc}
\hline Use & Rights & Irrigated Hectares & Annual Duty $\left(\mathrm{m}^{3} /\right.$ day $)$ \\
\hline Agriculture & 1 & 200 & $2,202.21$ \\
Agriculture & 1 & 200 & $2,202.21$ \\
Agriculture & 1 & 200 & $2,202.21$ \\
Stock diversion & 1 & NA & 34.26 \\
Stock diversion & 1 & NA & 34.26 \\
\hline
\end{tabular}

\section{Scenario 2-Mining}

With rising gold and silver prices, many gold and silver companies begin opening old claims and reopening abandoned mines. Within the Fairview Valley basin, only a single mine, The Bell Mountain Mine, is reopened, requiring additional needs for water resources to conduct mining activities. The close proximity of mining activities to the city of Fallon and little to no private land available within the basin result in no new construction of residential housing or other commercial buildings.

Previously withdrawn groundwater rights by the Bell Mountain Mining Company are requested and granted by the State Engineer's office, resulting in the drilling of five new wells (Table 3). Collectively, the wells yield 6,851 $\mathrm{m}^{3} /$ day. Due to the relative shallow depth of the gold and silver deposits and deep depth to groundwater, no dewatering is required. The combined total annual pumping for Scenario 2 and the existing water rights yield $7,079 \mathrm{~m}^{3} /$ day.

Table 3. $\quad$ Proposed water rights for Scenario 2.

\begin{tabular}{ccc}
\hline Use & Rights & Annual Duty (m³/day) \\
\hline Mining & 1 & $1,370.26$ \\
Mining & 1 & $1,370.26$ \\
Mining & 1 & $1,370.26$ \\
Mining & 1 & $1,370.26$ \\
Mining & 1 & $1,370.26$ \\
\hline
\end{tabular}

\section{Scenario 3-Urban Water Diversion}

Population centers within the state of Nevada continue to grow at their current rates, creating a need to acquire more in-state water resources. Las Vegas in particular, through the Southern Nevada Water Authority, continues to look to rural Nevada and expands its currently proposed groundwater applications to include the Fairview Basin. The State Engineer's office grants rights such that a single well is drilled in the basin and water is pumped through a pipeline to Las Vegas. The well is located on U.S. Department of Defense land to deter public access.

The single well is pumped at a rate to ensure groundwater withdrawal is just under the perennial yield for the basin (Table 4). The single well yields $7,585 \mathrm{~m}^{3} /$ day. The combined total annual pumping for Scenario 3 and the existing water rights yield $7,813 \mathrm{~m}^{3} /$ day. 
Table 4. Proposed water rights for Scenario 3.

\begin{tabular}{ccc}
\hline Use & Rights & Annual Duty (m²/day) \\
\hline Municipal & 1 & $7,585.39$ \\
\hline
\end{tabular}

\section{Results for Each Scenario}

The results for each scenario reflect the assumption that all current and scenario wells are allowed to extract water at the annual duty for 100 years. Therefore, within each scenario, pumping of the existing wells continues and new wells are added for water extraction. The continuation of current pumping in the Fairview Basin model domain results in no significant drawdown (Table 1). The existing water extraction from the basin is less than three percent of the perennial yield.

Scenario 1, agriculture, results in a groundwater level decrease in the northern portion of Fairview Basin. A 270-km² area centered on the three center pivot wells located in the northwest portion of the basin experiences more than $1 \mathrm{~m}$ of drawdown (Figure 10a). Although the aerial extent of groundwater level decrease is large, it does not include the PSA.

Scenario 2, mining, results in the smallest spatial extent of 1-m drawdown for the model domain. The $160-\mathrm{km}^{2}$ drawdown area occurs in the southeast portion of Fairview Basin and does not come close to the boundary of the PSA (Figure 10b).

Scenario 3, urban water diversion, results in the greatest spatial extent in 1-m drop in groundwater level for the model domain. The total area where a greater than 1-m decrease in water levels occurs is $345 \mathrm{~km}^{2}$. The groundwater level decrease occurs close to the center of the model domain (Figure 10c). The zone of decrease comes within $500 \mathrm{~m}$ of the PSA. Heavy pumping by the single well and the proximity of the well to the PSA causes this scenario to be of the most concern.

The three scenarios show different groundwater effects as a function of pumping rate and spatial location (Table 5). The effect of any planned activity will be dependent on the actual location and planned pumping rate. The scenarios are theoretical and intended to demonstrate the utility of a groundwater management tool for the PSA. The nature of the scenario analysis does indicate how multiple scenarios can be evaluated under different yield amounts. 


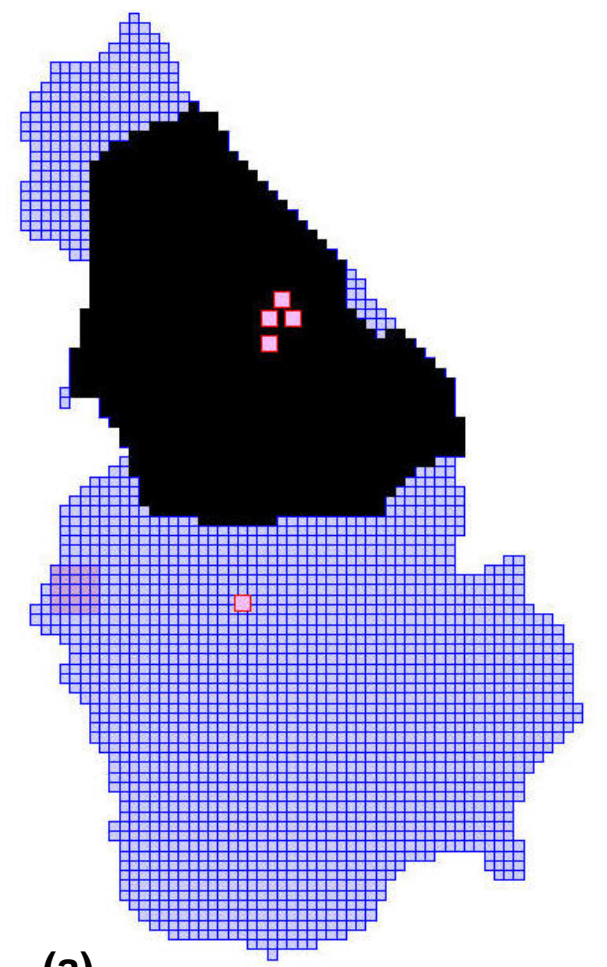

(a)
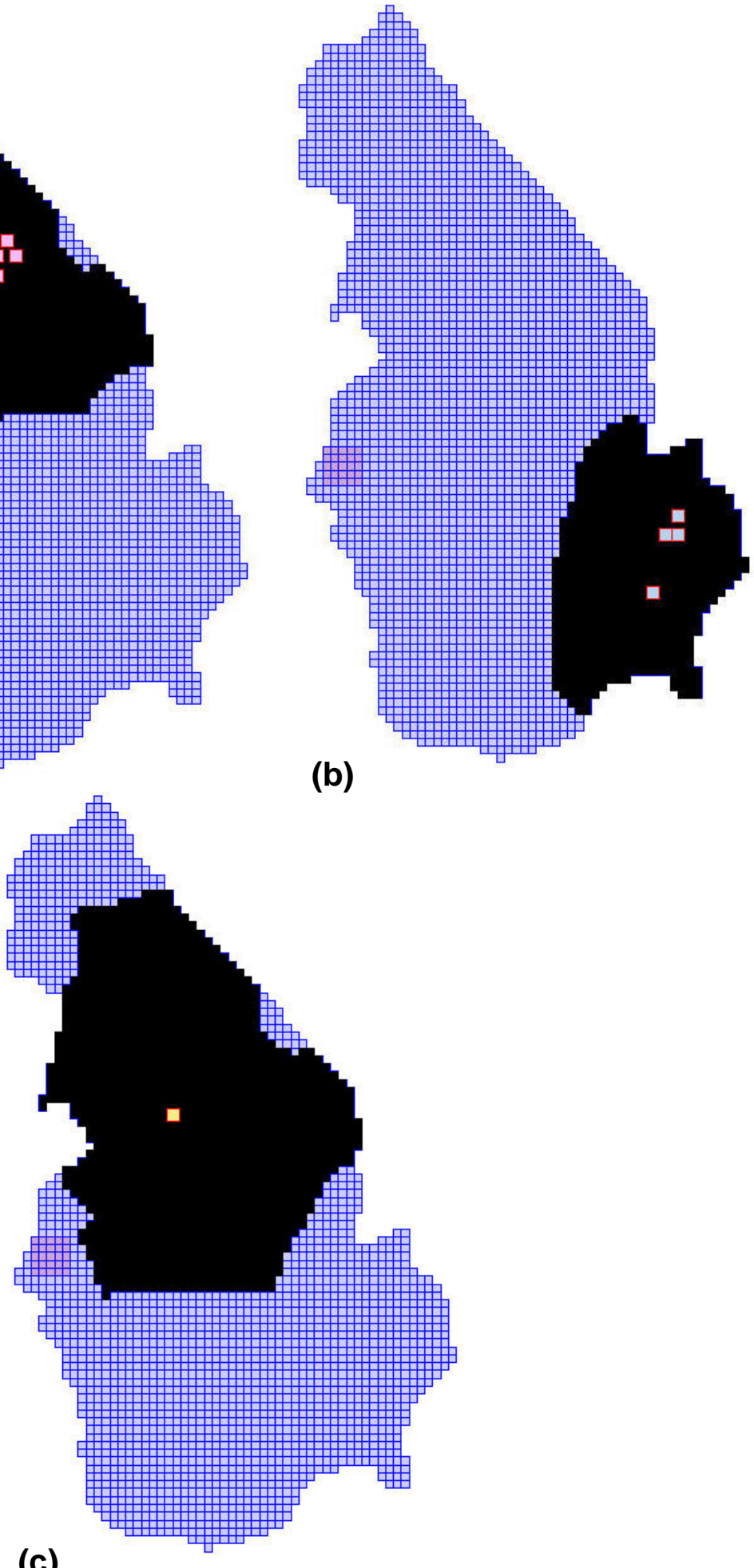

(c)

Figure 10. Results from (a) Scenario 1, (b) Scenario 2, and (c) Scenario 3. Shaded areas represent zones where predicted drawdown exceeds the specified threshold. 
Table 5. Area affected by hypothetical pumping scenarios.

\begin{tabular}{ccc}
\hline Scenario & $\begin{array}{c}\text { Total area with }>\text { 1-m drawdown } \\
\left(\mathrm{km}^{2}\right)\end{array}$ & $\begin{array}{c}\text { Percentage of total basin where } \\
\text { drawdown occurs }\end{array}$ \\
\hline Scenario 1 & 270 & 34 \\
Scenario 2 & 160 & 20 \\
Scenario 3 & 345 & 44 \\
\hline
\end{tabular}

\section{CONCLUSIONS}

Hypothetical future pumping scenarios were developed to demonstrate the utility of the PSA management model. Some or all of these scenarios may never occur. Nevertheless, the hypothetical scenarios provide insight into the potential consequences of increased pumping within Fairview Valley on the groundwater system at PSA.

The general conclusions that can be drawn from this study include:

1. The PSA management model provides an easy-to-use computer interface that will allow DOE and state personnel to evaluate the potential impact of proposed pumping within Fairview Valley on the PSA groundwater system.

2. This management model should be used only as a screening tool and not as the final model to evaluate radionuclide transport. Its primary purpose is to highlight when a potential change in pumping may alter radionuclide migration. If this tool suggests that groundwater levels will be impacted at the PSA, the high-resolution flow and transport model should be revisited to properly predict changes in radionuclide migration.

3. Pumping at current rates in existing wells, as allocated by the Nevada State Engineer, will not cause significant water level declines at PSA.

4. The impact of all proposed pumping scenarios is dependent on the number of wells, location of wells, and production rate. The management model allows these variables to be taken into account by the user.

\section{REFERENCES}

Carroll, R., K. Pohlmann, G. Pohll, and T. Mihevc, 2001. Investigation of hydraulic properties and groundwater levels related to the shear zone at the Project Shoal Site. Desert Research Institute, Publication No. 45183, DOE/NV13609--12.

Cohen, P. and D.E. Everett, 1963. A Brief Appraisal of the Ground-Water Hydrology of the Dixie-Fairview Valley Area, Nevada. State of Nevada, Department of Conservation and Natural Resources, Ground-Water Resources - Reconnaissance Series, Report 23.

Harrill, J.R. and L.B. Hines, 1995. Estimated Natural Ground-Water Recharge, Discharge, and Budget for the Dixie Valley Area, West-Central Nevada. U.S. Geological Survey, WaterResources Investigations Report 95-4052.

Hazelton-Nuclear Science Corporation., 1965. Post-Shot Hydrologic Safety, Project Shoal Final Report. U.S. Atomic Energy Commission, Vela Uniform Project Shoal, VUF-1014, $50 \mathrm{p}$.

Maxey, G.B., 1967. Hydrogeology of Desert Basins. Paper presented at Symposium on Ground-Water Development in Arid Basins, Logan, Utah. March 16-17, 1967, p. 10-22. 
Mihevc, T., G. Pohll and B. Lyles, 2000. Project Shoal Area Field Data Summary Report. Desert Research Institute, Publication No. 45175, DOE/NV/11508--54, 258p.

Pohll, G., J.T. Chapman, A. Hassan, L. Papelis, R. Andricevic, and C.T. Shirley, 1998. Evaluation of Groundwater Flow and Transport at the Shoal Underground Nuclear Test, Desert Research Institute, Publication No. 45162, DOE/NV11508--35.

Pohll, G., A.E. Hassan, J.B. Chapman, C. Papelis, and R. Andricevic, 1999. Modeling ground water flow and radioactive transport in a fractured aquifer. Ground Water, 37(5): 770-784.

Pohll G., 1999. Evaluation of surface recharge flux for the Project Shoal Area. Desert Research Institute, Publication No. 45171, DOE/NV/11508--49, 18p.

Pohlmann, K., G. Pohll, J. Chapman, A. Hassan, R. Carroll, and C. Shirley, 2003. Modeling to Support Groundwater Contaminant Boundaries for the Shoal Underground Nuclear Test. Desert Research Institute, Publication No. 45184, DOE/NV13609--13.

Reimus, P., G. Pohll, T. Mihevc, J. Chapman, M. Haga, B. Lyles, S. Kosinski, R. Niswonger, and P. Sanders, 2003. Testing and parameterizing a conceptual model for solute transport in a fractured granite using multiple tracers in a forced-gradient test. Water Resources Research, 39(12):1356-1370.

Shearer, A.W., D. A. Mouat, S.D. Bassett, M.W. Binford, C.W. Johnson, and J.A. Saarinen, 2006. Examining development-related uncertainties for environmental management: Strategic planning scenarios in Southern California. Landscape and Urban Planning, 77(4):359-381.

Schwartz, P., 1996. The Art of the Long View. Doubleday. New York, NY. 272 pp.

University of Nevada, 1965. Geological, Geophysical, Chemical, and Hydrological Investigations of the Sand Springs Range, Fairview Valley, and Fourmile Flat, Churchill County, Nevada. Vela-Uniform Program, VUF-1001.

U.S. Department of Energy, 2000. United States Nuclear Tests July 1945 through September 1992. Nevada Operation Office, DOE/NV--209-Rev 15. 


\section{DISTRIBUTION}

Jenny Chapman

Division of Hydrologic Sciences

Desert Research Institute

755 East Flamingo Road

Las Vegas, NV 89119-7363

Jacqueline Van Lier

Stoller-Navarro Joint Venture

7710 W. Cheyenne

Las Vegas, NV 89128

Director

Environmental Restoration Division

Nevada Site Office

National Nuclear Security Administration

U.S. Department of Energy

P.O. Box 98518

Las Vegas, NV 89193-8518

Bruce Hurley

Hydrology Program Manager

Environment, Safety and Health Division

Nevada Site Office

National Nuclear Security Administration

U.S. Department of Energy

P.O. Box 98518

Las Vegas, NV 89193-8518

Tim Echelard

Stoller-Navarro Joint Venture

P.O. Box 93838, M/S 439

Las Vegas, NV 89193-3838

Kenneth A. Hoar, Director

Environment, Safety and Health Division

Nevada Site Office

National Nuclear Security Administration

U.S. Department of Energy

P.O. Box 98518

Las Vegas, NV 89193-8518
Richard Hopper

Deputy Laboratory Directory

U.S. Environmental Protection Agency

Radiation and Indoor Environments National

Laboratory

4220 S. Maryland Parkway, Bldg. C

Las Vegas, NV 89119

Rick Hutton

Stoller Grand Junction

2597 B 3 / 4 Road

Grand Junction, CO 81503

John Jones

Environmental Restoration Division

Nevada Site Office

National Nuclear Security Administration

U.S. Department of Energy

P.O. Box 98518

Las Vegas, NV 89193-8518

Marjory Jones

Division of Hydrologic Sciences

Desert Research Institute

2215 Raggio Parkway

Reno, NV 89512-1095

Randy Laczniak

U.S. Geological Survey

Water Resources Division

160 N. Stephanie St.

Henderson, NV 89074-8829

Tom Pauling

Office of Land and Site Management

Office of Legacy Management

U.S. Department of Energy

25973 / 4 Road

Grand Junction, CO 81503 
Peter Sanders

Environmental Restoration Division

Nevada Site Office

National Nuclear Security Administration

U.S. Department of Energy

P.O. Box 98518

Las Vegas, NV 89193-8518

David Shafer

Division of Hydrologic Sciences

Desert Research Institute

755 E. Flamingo Road

Las Vegas, NV 89119-7363

Nevada State Library and Archives

State Publications

100 North Stewart Street

Carson City, NV 89710-4285

Archives

Getchell Library

University of Nevada, Reno

DeLaMare Library/262

University of Nevada, Reno

Document Section, Library

University of Nevada, Las Vegas

4505 Maryland Parkway

Las Vegas, NV 89154

Library

Stoller-Navarro Joint Venture

7710 W. Cheyenne, Bldg. 3

Las Vegas, NV 89128

ATTN: Toni Miller

Library

Southern Nevada Science Center

Desert Research Institute

755 E. Flamingo Road

Las Vegas, NV 89119-7363
Technical Library

Nevada Site Office

National Nuclear Security Administration

U.S. Department of Energy

P.O. Box 98518

Las Vegas, NV 89193-8518

Public Reading Facility

c/o Nuclear Testing Archive

Nevada Site Office

National Nuclear Security Administration

U.S. Department of Energy

P.O. Box 98521, M/S 400

Las Vegas, NV 89193-8521

Office of Scientific and Technical

Information

U.S. Department of Energy

P.O. Box 62

Oak Ridge, TN 37831-9939

(electronic copy) 